\title{
Martin-Dietrich Glessgen, Lingvistică romanică. Domenii și metode în lingvistica franceză și romanică, Cuvînt înainte și traducere de Alexandru Gafton, Editura Universității „Alexandru Ioan Cuza”, Iași, 2014, 652 p.
}

\author{
Cosmin Căprioară ${ }^{*}$ \\ Facultatea de Litere, Universitatea „Ovidius” din Constanța, Aleea Universității 1, 900472 Constanța, România
}

Lucrarea lui Martin-Dietrich Glessgen, Linguistique romane. Domaines et méthodes en linguistique française et romane, apărută în 2007, într-o primă ediție și, apoi, în 2012, în ediția a doua, revizuită, la prestigioasa editură Armand Colin din Paris, cunoaște, din 2014, şi o versiune românească, apărută la Editura Universităţii „Alexandru Ioan Cuza” din Iași. Este o apariție binevenită și necesară, cu atît mai mult cu cît de citeva decenii la noi nu a mai văzut lumina tiparului o traducere a marilor lucrări occidentale de romanistică.

M.-D. Glessgen este un eminent romanist contemporan, profesor de lingvistică romanică și lingvistică istorică franceză la Universitatea din Zürich, director al Institutului de Lingvistică Romanică de aici, secretar-administrator al Societé de Linguistique Romane și redactor-șef al Revue de Linguistique Romane. Totodată, el este unul din editorii manualului Histoire linguistique de la Romania (3 vol., apărut la De Gruyter, Berlin/New York, între 2004 și 2008).

Traducerea românească i se datorează unei personalităţi a lingvisticii diacronice românești, profesorului Alexandru Gafton de la Universitatea ieșeană, care semnează și Cuvîntul înainte, în care deplînge scăderea severă, în lingvistica românească, „a interesului pentru romanistică şi pentru studierea limbii din perspectivă diacronică, în general” (p. 13), și unde subliniază valoarea și importanța lucrării romanistului german, care „dezvoltă și deține calitățile unui model” (p. 14). Traducătorul, ca un specialist al literelor, înțelege cel mai bine sensul travaliului depus de autor și, într-o formă fluentă, coerentă și convingătoare, transpune în română textul, ale cărui subtilități le urmărește îndeaproape și le respectă.

Așa cum arată autorul încă din Prefață, avem de-a face cu un manual, de a cărui necesitate și utilitate s-a convins de-a lungul carierei sale, din discuțiile cu studenții și din analiza manualelor de lingvistică romanică apărute pînă în prezent, cu ocazia unui seminar ținut la Universitatea din Jena. Tot acesta observă că „textul este dens și solicitant pentru o introducere; tocmai datorită acestui fapt, însă, el permite o învățare intensivă, cu păstrarea calităților sale de unic volum, față de manualele în mai multe volume" (p. 23). Cu modestie, autorul recunoaște complementaritatea manualului său cu cele al lui C. Tagliavini (Le origini delle lingue neolatine) și P. Bec (Manuel pratique de philologie romane) și își exprimă prețuirea pentru opera lui $\mathrm{H}$. Lausberg în domeniul foneticii și morfologiei istorice romanice (Romanische Sprachwissenschaft), precum și dorința de a îndemna cititorul către alte mari manuale de romanistică, mai recente: Lexikon der Romanistischen Linguistik (LRL; editori: G. Holtus, M. Metzeltin, C. Schmitt, 12 vol., Niemeyer, Tübingen, 1988-2005), Romanische Sprachgeschichte / Histoire linguistique de la Romania (RSG; editori: G. Ernst, M.-D. Glessgen, C. Schmitt, W. Schweickard, 3 vol., De Gruyter, Berlin/New York, 2003-2008) ori Cambridge History of Romance Languages (CambrHist; autori: M. Maiden, J.C. Smith, A. Ledgeway, Cambridge/New York, 2 vol., 2011-2013).

Manualul este structurat în patru părți, precedate de o parte introductivă și urmate de un aşa-numit Capitol 5, care cuprinde siglele folosite și bibliografia, bogată și actualizată, a domeniului.

În partea introductivă, Limbile romanice și lingvistica (p. 35-69), se face mai întîi încadrarea în context, prin intermediul unui tabel ilustrativ al ramurilor familiei limbilor indoeuropene, după care, în capitolul preliminar, Lingvistica romanică și structura manualului, se prezintă fundamentele științifice şi metodologice ale manualului. Autorul reiterează marile adevăruri ale disciplinei. Pornind de la fap-

*Adresă de corespondență: ct.caprioara@yahoo.fr. 
tul cunoscut că limbile romanice „s-au născut din aceeași bază, variantele latinei vorbite în antichitatea tîrzie (latină tîrzie vorbită), ca urmare a diferențierii şi a divergenței” (p. 35), el subliniază importanța studierii acestora. Locul ocupat de familia limbilor romanice în cadrul familiei indoeuropene este important nu atît prin dimensiune, cît prin faptul că cercetătorii beneficiază de cunoașterea foarte precisă a limbii mamă comune, latina, prin evoluția lor bine documentată cu surse scrise de-a lungul celui de-al doilea mileniu și prin aceea că ele constituie un laborator de observare unic, în condițiile în care mai puțin de $10 \%$ din limbile Pămîntului sînt descrise de o manieră satisfăcătoare și foarte puține dispun de documentație istorică. Marea forță a romanisticii constă în reflecțiile istorice, comparative și variaţionale cărora le dă viață și care pot avea „o contribuție reală la înțelegerea funcționării lingvisticii în general" (p. 36). În plus, multe din observaţiile realizate în context romanic sînt valabile și pentru alte limbi. În această ordine de idei, unul din obiectivele fundamentale ale manualului îl reprezintă trezirea unei „conștiințe romanice” la studenții de la secțiile de franceză, italiană, spaniolă sau română, care se pot familiariza cu idiomurile neolatine, chiar fără să le cunoască în profunzime.

Sînt prezentate, în continuare, cele patru părți ale lucrării, dedicate, pe rînd, descrierii succinte a idiomurilor romanice actuale şi studiului lor din perspectivă variațională și pragmatică, domeniilor fundamentale ale limbii (fonetică/fonologie, morfologie, sintaxă, lexic), din perspectiva schimbării lingvistice, istoriei Romaniei într-o viziune sociolingvistică şi unor aspecte fundamentale legate de practica și teoria cercetării romanice, cu referire directă la bazele filologice și la istoria lingvisticii romanice.

Din dorința de a-i oferi cursantului o viziune integratoare, sînt prezentate conceptele fundamentale, precum cel de limbaj, limbă, lingvisticăa funcțiile limbajului, după K. Bühler și R. Jakobson, precum şi problemele pe care lingvistica le abordează. Aceasta este văzută în relațiiile ei cu limba și cu societatea, iar cele două ramuri ale sale-lingvistica sistemică și cea variațională—își găsesc aplicabilitatea în cazul limbilor particulare ori în situația comparării limbilor diferite, din punct de vedere sincronic și diacronic. Esențiale pentru înţelegerea fenomenelor lingvistice sînt, în opinia autorului, compararea limbilor, inclusiv din perspectivă tipologică, precum și studiul lor diacronic. Acestora li se adaugă cuceriri mai noi, cum sint: cercetarea limbilor creole, a limbajului surdomuților şi dezvoltarea unor ştiințe de graniță: psihoși neurolingvistica.

Foarte utilă şi inspirată în cadrul unui manual, în tradiția lui Tagliavini, dar cu o aducere la zi modernă, este inserarea unui subcapitol privitor la Lucrările de referință în lingvistica romanică: mari manuale și lucrări introductive, enciclopedii romanice (din păcate, nu se face deloc referire la Enciclopedia limbilor romanice, apărută la București în 1989 sub coordonarea lui M. Sala!). De asemenea, sint indicate marile bibliografii uzuale ale romanisticii, cum ar fi Romanische Bibliographie, Bibliographie romane, Romance Bibliography (RB), inițiată în 1878, cu apariție anuală, avînd și o versiune informatizată.

Prima din cele patru părți propriu-zise ale manualului, intitulată Limbile și varietățile romanice actuale (p. 71-185), se deschide cu un capitol complex, bogat în informație, dar, totodată, compact și ușor de lecturat și de utilizat (Prezentarea limbilor romanice), cum, de altfel, sint toate capitolele introductive, în care M.-D. Glessgen vrea să îi ofere lectorului toate instrumentele necesare înțelegerii aprofundate a problematicii discutate ulterior. Se face, mai întîi, o necesară precizare a termenilor: limbă, dialect, idiom, varietate, în context romanic. Merită reținută tipologia limbilor romanice, realizată în funcție de gradul de prezență/absență a criteriilor interne (precum distanţa - diferențierea dintre o varietate și alta) și externe (elaborarea lingvistică), urmînd terminologia germanistului H. Kloss (Abstandssprache - 'limbă prin distanţare', respectiv Ausbausprache - 'limbăprin elaborare'). Astfel, se pot distinge, în Romania, limbi prin distanțare și prin elaborare (franceza, italiana, româna), limbi distanțate care nu au cunoscut o elaborare sistematică (franco-provensala), varietăți dialectale, lipsite de un grad ridicat de elaborare și de distanțare (cum ar fi dialectul venețian) și limbi sau varietăți rezultate prin 'pură' elaborare, cu autonomie internă slabă (precum corsicana ori spaniola din America).

Punctul de plecare pentru prezentarea limbilor romanice în Europa și în lume îl constituie reprezentarea cartografică propusă de W. von Wartburg în 1950, dar modernizată și corectată de M.-D. Glessgen (p. 78). Sînt descrise Romania continua, din care, în trecut, făcea parte și româna, Romania 
submersa, cunoscută și ca Romania perduta, și Romania nova, extreuropeană. Autorul pune cîteva accente necesare din punctul său de vedere. Astfel, subliniază că „dialectele, iar nu limbile standard apărute apoi, prin elaborare lingvistică, sînt singurele continuatoare ale latinei" (p. 77). Practic, idiomurile romanice actuale sînt tributare națiunilor contemporane și 'spațiilor comunicaționale' formate de acestea. Rolul 'limbilor-acoperiş' (= limbile naționale standardizate) dominante este asumat de limbile naționale: portugheză, spaniolă, franceză, italiană, romanșă/retoromană și română. Adresîndu-se în special unui public centrat pe spaţiul francofon și înconjurător, autorul continuă cu descrierea diviziunilor geolingvistice din Galo- și Italoromania, făcînd o incursiune în dialectologia sincronică și diacronică. Avînd în vedere cîteva criterii (numărul vorbitorilor, limbile de contact, elaborarea unui aspect scris și importanța dialectelor), autorul face o descriere a caracteristicilor externe ale francezei, occitanei, gasconei (considerată, eventual, dialect al limbii d'oc), francoprovensalei, italienei, sardei, romanșei, ladinei și friulanei, spaniolei, catalanei, valencianei și graiurilor din Insulele Baleare, galicianei, portughezei și românei, cele 14 idiomuri romanice luate în considerare de acesta. Două mari teme încheie primul capitol al acestei părți. Cea dintîi, elemente de tipologie intraromană, oferă o detaliere a tipologiei lingvistice propuse mai sus pentru fiecare idiom romanic, o ilustrare practică și comentată a variației lingvistice romanice pe baza unui fragment din Tatăl nostru, ca și o 'reluare' reflexiv-critică a clasificărilor mai cunoscute ale limbilor romanice. În fața complexității problemei, autorul acceptă, din rațiuni practice, că ar fi, eventual, „acceptabil să facem apel la etichetele deja consacrate, precum iberoromanică, galoromanică, italoromanică" (p. 122) și „dacoromanică” (sau „Romania de sudest"), reprezentată, astăzi, numai de română. A doua temă se referă la contactul lingvistic din Romania, contact care poate duce la diglosie/poliglosie, din care pot rezulta bilingvismul/plurilingvismul. Interesantă, dar cu care nu putem fi în întregime de acord, este ideea amestecurilor de limbi dintre idiomuri romanice și neromanice, în urma cărora ar fi rezultat anglo-normanda și chiar româna. Caracterul romanic al acesteia din urmă ar fi „efectul parțial al relatinizărilor și francizărilor, operate în vremea elaborării sale, din secolul al XIX-lea, și care au redus numărul elementelor de origine slavă” (p. 126). Se cunoaște însă că apartenența la un grup lingvistic este dată, în cea mai mare parte, de morfologie, iar morfologia românei este aproape în totalitate de origine latină.

Capitolul următor, Studiul limbilor romanice sub aspect variațional, pune în relație domeniul romanic cu lingvistica variațională, ale cărei baze au fost puse de L. Flydal și, într-o formă reelaborată, de E. Coșeriu, în 1966. Ca de obicei, un preambul metodicoteoretic dens deschide capitolul, cu circumscrierea variației lingvistice, ca și cu observarea limitelor acesteia, datorate principiilor de comprehensibilitate, gramaticalitate și accesibilitate care guvernează comunicarea umană. Un prim tip variaţional este cel diatopic, variația în spațiu a latinei vorbite permițînd apariţia unor dialecte primare, aflate la originea idiomurilor romanice, care, ulterior, au dezvoltat, la rîndul lor, varietăți teritoriale, altfel spus dialecte secundare. Este prilejul pentru o prezentare a metodei geografiei lingvistice, a instrumentelor de lucru ale dialectologului și a rezultatelor cercetărilor dialectale, printre care atlasele lingvistice, de care limbile romanice beneficiază din plin. Este regretabil că nu se face nici o referire la atlasele lingvistice românești (ALR și ALRR/NALR), realizate cu un înalt nivel de profesionalism și apreciate de specialiști!

Complexitatea variației lingvistice implică, alături de variația diatopică, și diferențele dintre categoriile de vorbitori (variația diastratică) și dintre 'genurile textuale' (variația diafazică), interdependente în cadrul lanțului variațional, care, manifestat în diferitele compartimente ale diasistemului limbilor romanice, sporește dificultatea, dar și facilitează, în acelaşi timp, cercetările lingvistice comparate. Dacă variaţia diatopică este obiectul de studiu predilect al dialectologiei, sociolingvistica se ocupă de variația diastratică, aflată în strînsă conexiune cu cea diafazică. În cazul acestora din urmă, trebuie subliniată importanța prestigiului lingvistic în organizarea lor. Prestigiul poate fi pus în legătură cu apropierea și distanţa lingvistică, atît în aspectul oral, cît și în cel scris, distanța fiind puternic întărită prin scris.

Cel din urmă capitol al primei părți este dedicat lingvisticii textuale și pragmatice, cu referire directă la domeniul romanic. Avem de-a face, practic, cu introduceri calificate în teoria genurilor textuale și în pragmatică, precum și cu descrierea modului în care acestea interrelaționează. 
Partea a doua a lucrării, cea mai cuprinzătoare, se referă la Structurile și istoria internă a limbilor romanice (p. 187-429). Autorul segmentează, mai întîi, materialul lingvistic romanic, după patru mari domenii ale limbajului, considerate fundamentale pentru conturarea cadrului descriptiv al fiecărei limbi și pentru o mai bună înțelegere a istoriei interne: fonetica și fonologia, morfologia flexionară și formarea cuvintelor, sintaxa și, în fine, lexicul, inclusiv numele proprii (onomastica și toponomastica), alocînd fiecăruia cîte un capitol. Se fac interesante considerații de ordin epistemologic despre aceste domenii, precum și despre relațiile dintre ele. De asemenea, se fac necesare precizări referitoare la conceptul de „gramatică” și la felul în care este înțeles acesta, mai ales din punct de vedere generativist și constructivist. Inedită pentru studiile de romanistică este discuția, inclusă într-un subcapitol interdisciplinar, despre contribuțiile neuropsihologiei la teoria lingvistică. În unirea foneticii cu fonologia, separarea sintaxei de morfologie şi tratarea împreună a formelor lexicale și a conceptelor, autorul se bazează pe componenta anatomică a limbajului. Cititorii sînt familiarizaţi cu termeni de specialitate, precum aria lui Broca, aria lui Wernicke, centri responsabili de 'modulele' fonetic, fonologic, morfologic și sintactic, al lexicului și al conceptelor, memorie 'declarativă, memorie 'proceduralü' s.a. În continuare, sînt evidențiate relațiile de interdependență dintre diferitele domenii sau module ale limbajului, precum și fenomenul de 'gramaticalizare', care leagă morfologia de sintaxă și prin intermediul căruia un lexem poate deveni gramem (cum s-a întîmplat în latina vorbită cu ille, devenit marcă a determinării). Fenomenele lingvistice nu puteau fi tratate în absența unei periodizări a limbilor romanice, pentru care se face apel la istoria 'externă, căreia, de altfel, autorul îi alocă un spațiu aparte. Periodizarea 'externă' este jalonată de cele trei mari 'granițe': căderea Imperiului Roman, în 476, avîntul Occidentului, din secolul al XI-lea, și Renașterea, inclusiv descoperirile extraeuropene. Periodizarea 'internă' este mult mai greu de realizat, dar se poate susține că o mutaţie internă foarte importantă s-a produs în preajma anului 700 (în secolul dintre 650 și 750), marcînd trecerea de la latină la limbile romanice, iar o a doua a avut loc mai tîrziu, în secolul al XVI-lea, reprezentînd trecerea de la limbile romanice medievale la cele moderne (v. p. 197-200). Pentru franceză, bine reprezentată din acest punct de vedere, se dă un exem- plu de periodizare în funcție de producția de texte. Demnă de reținut, în acest context, este remarca terminologică a autorului, care respinge termenul de latină vulgară și propune folosirea fie a lui protoromană/protoromanică (protoromane, în franceză), fie a termenului latină vorbită pentru „orice formă latinească orală, care a cunoscut o evoluție ereditară (subl. aut.) către o limbă romanică” (p. 200), adică a fost moștenită.

Cum arătam mai sus, domeniile limbajului sînt tratate de autor rînd pe rînd, în capitole separate. Binevenită este punerea în relație a foneticii și fonologiei, care sînt descrise epistemologic inclusiv pentru neiniţiaţi, cu grafematica și ortografia. Este un prilej nimerit pentru a sublinia utilitatea cunoașterii aspectelor privitoare la grafeme și ortografie pentru cel care studiază diacronic o limbă, avînd la dispoziție exclusiv texte scrise. Într-un mod clar și concis, îi sînt prezentate lectorului interesat: perechile minimale, raportul dintre sunete și foneme, foneme și alofone, tipologia sunetelor, respectiv a fonemelor romanice, vocalismul accentuat și neaccentuat romanic, consonantismul romanic, diftongările şi monoftongările, transformările cu caracter regulat și unele de tip accidental, precum și importanța latinizărilor și relatinizărilor pentru Romania occidentală. Foarte utilă este partea alocată tipurilor de silabă și rolului prozodiei în evoluţia fonetică a limbilor romanice.

Morfologia este prezentată sub dubla înfățișare, de știință care trebuie să se refere la „structura internă a cuvintelor (...), luînd în seamă atît flexiunea, cît și formarea cuvintelor" (p. 253). În mod firesc pentru manualul de faţă, sînt definite și detaliat prezentate concepte de bază ale domeniului (lexem, gramem, formă gramaticală, lexem simplu, lexem construit, frazem, locuţiune etc.). Structura morfologică nu mai poate fi redusă la ,concatenarea de morfeme atomice” (p. 260), abordările mai recente sprijinindu-se pe lexem și pe gramem.

Pe latura de morfologie propriu-zisă, după ce sînt trecute în revistă flexiunea, principalele sale caracteristici, categoriile gramaticale („trăsăturile morfosintactice”) și clasele flexionare, se continuă cu descrierea practică a principalelor transformări cunoscute în trecerea de la latină la limbile romanice de flexiunea nominală, de adjectiv, de sistemul pronominal și, parţial, de paradigmele verbale, unde sînt reținute indicativul prezent, imperfect și viitor în franceză, italiană și spaniolă. În ceea ce privește formarea 
cuvintelor, sînt alocate spații adecvate derivării (atît sub aspectul prefixării, cît și al sufixării), ca principal procedeu de formare de noi unități lexicale în spațiul romanic, compunerii, dar și altor procedee de îmbogăţire a lexicului, cum sînt abrevierile şi acronimele, delocutivele, încrucișările de cuvinte și defigurările formale voluntare (ca în verlang, din fr. à l'envers). Se impun cîteva precizări pentru publicul românesc, legate de terminologia folosită. Astfel, prin conversiune autorul înțelege fie derivarea cu un afix flexionar (it. pianta $\rightarrow$ it. piantare), fie derivarea regresivă (it. arrivare $\rightarrow$ it. arrivo), prin derivare improprie, numită și „derivare zero”, conversiunea (it. il fare „acțiunea de a face"), prin schimbarea genului, derivarea cu sufixe moționale, iar prin parasinteză, derivarea parasintetică (p. 290).

Capitolul alocat sintaxei este la fel de generos în detalii de natură epistemologică și metodologică, care fac trecerea la descrierea, din perspectivă modernă, a grupurilor nominal (GN) și verbal (GV) și a propoziției în limbile romanice. Informațiile referitoare la grupul verbal le completează pe cele oferite deja în capitolul anterior, iar la p. 322 se dă și un rezumat al transformărilor latino-romanice petrecute în cadrul sistemului verbal. Privitor la propoziția romanică, se pornește de la premisa că în ciuda unui conținut asertiv comun, formele lineare ale exprimării acestuia pot fi diferite chiar și în interiorul aceleiași limbi. Redarea unei ierarhii semantico-pragmatice prin structuri lineare (în timp, iar în scris, și în spațiu) se poate face în moduri foarte diverse. Totuși, configurația (distribuția) elementelor componente și marcajul gramematic impun anumite restricții, reducînd posibilitățile de exprimare ale unui conținut asertiv. Sînt tratate patru ansambluri fundamentale pentru studiul (diacronic) al propoziției din limbile romanice: ordinea constituenților (de la o ordine latinească SOV s-a ajuns la o ordine romanică mai mult sau mai puțin rigidă SVO), funcțiile actanțiale (patru roluri actanţiale fiind mai frecvente: agent, pacient, destinatar și beneficiar, urmate de unele, întîlnite destul de des: experient, instrumental și locativ, și, mult mai rar, de rolurile: modal, temporal și rezultativ), structura informațională (ordinea temăremă domină limbile romanice contemporane) și subordonarea (marcată, de obicei, conjuncțional și întărită datorită dezvoltării aspectului scris). Un rezumat al schimbării latino-romanice în morfologie și sintaxă ne este oferit la p. 350 sqq., după ce se face o trecere în revistă a principalelor gramatici romanice (occidentale).

Un spaţiu generos este alocat lexicologiei, în capitolul omonim. Bazele teoretice ale științei sînt descrise cu obişnuita competență a autorului, ca și diferite aspecte ale teoriei semiotice (vezi, de exemplu, p. 363-367, pentru triunghiul, trapezul, pentagonul și pătratul semiotic, corespunzînd diferitelor teorii despre natura semnului lingvistic). Urmează descrierea legăturilor dintre schimbarea romanică și relațiile semantice. Este vorba, în special, despre rolul sinecdocei, metonimiei și metaforei, subsumate expresivității, în evoluția semantică a lexemelor latinești. $\mathrm{Nu}$ sînt uitate modificările datorate unor motive formale, de tipul etimologiei populare sau elipsei (it. borsa di studi $\rightarrow$ it. borsa). Obișnuit al abordărilor inter- și transdisciplinare, M.-D. Glessgen se ocupă, printre altele, în acest capitol, de interpretarea istorică şi antropologică a schimbărilor semantice (p. 388 sqq.), dar și de onomasiologia istorică (p. 389 sqq.). Frazeologia este tratată în strînsă legătură cu contextul, iar împrumuturilor lexicale romanice li se acordă atenţia cuvenită. Practic, cititorul are în faţă un mic tratat asupra împrumuturilor lingvistice, cuprinzînd date despre contactele lingvistice din timpul Imperiului Roman și de mai tîrziu, tipologia împrumuturilor, drumul și modificările suferite de acestea, importanța lor cantitativă, dificultăţi în stabilirea originii împrumuturilor ș.a.m.d. Un element rar întîlnit în manualele de romanistică îl reprezintă onomastica și deonomastica romanice, cărora autorul le prezintă fundamentele în cuprinsul citorva pagini. Cum este și firesc într-o cercetare diacronică, lexicologia este pusă în relație cu etimologia, iar ca o încununare a capitolului, sînt puse la dispoziția celor interesați cele mai utile și recente instrumente de lucru, dicționarele istorice și etimologice ale francezei și ale altor limbi romanice. Pentru română sînt reținute: Dicționarul etimologic al lui Al. Ciorănescu, Etymologisches Wörterbuch al lui S. Pușcariu și Rumänisch-deutsches Wörterbuch al lui H. Tiktin, reeditat de P. Miron.

Partea a treia cuprinde tratarea Istoriei externe a limbilor și a varietăților romanice (p. 431-538). Mai întîi, în Introducere, este subliniată legătura indisolubilă dintre istoria internă a unei limbi și cea externă, a societăţii din care fac parte vorbitorii acelei limbi: „Istoria externă este pandantul indispensabil al istoriei interne (...) Cele două perspective sînt interde- 
pendente." (p. 433). Lingvistica istorică este obligată să se sprijine, de fapt, pe istoria limbilor standard, de obicei fixate în scris de-a lungul timpului. Problematica istoriei externe a Romaniei are o importanță metodologică nu numai pentru romanistică. Aceasta privește, în special, fragmentarea Romaniei, altfel spus trecerea de la latină la limbile romanice, fixată de autor și nu numai în preajma anului 700, notarea în scris şi standardizarea limbilor romanice, începînd cu Evul Mediu, și apariţia diasistemelor lingvistice complexe. Determinanți pentru istoria externă sînt, în concepția autorului, patru factori, pe care îi are în vedere în descrierea fiecărei etape de evoluție a limbilor romanice. Aceștia sînt: spaţiul şi demografia, contactul lingvistic, infrastructura și organizarea socioculturală, politică și economică și, nu în ultimul rînd, cultura scrisului, reflecția lingvistică și diasistemul, ultimii doi reprezentînd factori de mare complexitate. Etapele de evoluție a societăţii romanice sînt tratate separat în cadrul cîte unui capitol. Prima etapă, epoca romană, de la începuturi pînă în secolul al V-lea, prezintă expansiunea romană și aspectele complexe ale procesului de romanizare („latinizare”), prin care noii supuşi „se adaptau la limba latină, mai întîi ca limbă de circulație (subl. aut.), apoi ca limbă de comunicare curentă și, în cele din urmă, ca limbă maternă” (p. 446), contactul lingvistic (de substrat, adstrat și superstrat) și contribuția acestuia la fragmentarea Romaniei, precum și diferitele cauze care au dus la regionalizarea latinei, de altminteri o limbă destul de omogenă. Capitolul următor urmărește geneza Romaniei, adică perioada dintre secolele al V-lea și al X-lea. Trecerea de la latină la limbile romanice a fost posibilă prin contribuția mai multor factori, printre care, la loc de frunte, se află: distrugerea Imperiului Roman, dezintegrarea infrastructurilor (drumuri, administrație, școli, jurisdicții) și tulburări ale diasistemului, mai precis întreruperea 'comunicării pe verticală' (termen preluat de la M. Banniard), adică nemaiînțelegerea de către analfabeți a latinei scrise, citite cu voce tare. Perioada critică, în care mai multe particularități lingvistice novatoare s-au restructurat la nivelul unor sisteme noi, în care transformările lingvistice par să se fi accelerat, operînd asupra a trei generații, și cînd oralitatea s-a restructurat și ca urmare a slăbirii vechii norme scrise (factor adăugat de Glessgen), ar putea fi secolul cuprins între 650 și 750 (v. RSG art. 51). În orice caz, spre anul 1000, contemporanii aveau conștiința unui clivaj între „limba erudită, scrisă și vorbită în cercuri restrînse (și utilizată în public în ocazii formale), și o limbă de comunicare (subl. aut.), maternă, cotidiană, aproape exclusiv vorbită” (p. 455). De fapt, în scris se puteau folosi trei tipuri diferite de „elaborare lingvistică: latina standard sau normată, latina rustică și romanica” (p. 470), ceea ce se putea traduce printr-o triglosie conștientă. Privitor la noua geografie a spațiului romanic, româna se bucură de o tratare echilibrată, aparte (p. 458-460), în calitate de contraexemplu valoros al caracteristicilor spațiului contiguu al Romaniei centrale și occidentale (fiind singura limbă romanică izolată, vorbită de o populație ortodoxă și influențată de slavă), poate și datorită articolelor din RSG scrise de reputații I. Fischer și St. Dumistrăcel (vezi și considerațiile demne de atenție din Cuvîntul înainte, privitoare la ponderea şi tratamentul limbii române în manual, p. 17-20).

Romania in Evul Mediu timpuriu (secolele al XIlea - al XV-lea) este capitolul următor, în care sînt analizate, într-o primă fază, reconquista iberică, constituirea Dacoromaniei şi cucerirea Angliei de către normanzi. Urmează referiri la cruciade, la dominația venețiană asupra Dalmației și la rolul negustorilor italieni și iberici în spațiul mediteranean, respectiv atlantic. Este o epocă caracterizată de stabilitate și de fluctuații în interiorul spațiilor constituite, Biserica avînd un rol determinant, inclusiv în dezvoltarea culturii scrisului. Este „epoca de avînt a limbilor romanice, de întemeiere a bazei lor teritoriale europene și a primei lor elaborări, sub tutela latinei, desigur. (...) Este epoca unui plurilingvism (subl. aut.) nedogmatic și puțin conflictual, întemeiat pe varietățile vorbite și scrise, de dimensiuni regionale" (p. 498). Capitolul 3.5 este dedicat Epocii moderne (1500 - sfirșitul secolului al XIX-lea), care este „martorul genezei limbilor romanice standard (subl. aut.)" (p. 499), al constituirii așa-numitelor 'limbi-acoperiş, al dezvoltării impresionante a scrisului, impulsionat de inventarea tiparului, al înfloririi reflecției asupra limbii, al apariției legislației lingvistice și a academiilor etc. Româna cunoaște o etapă de elaborare parțială. Epoca contemporană (1880-2000) este tema următorului capitol. Acum, problema aflată în fața cercetătorului romanist este abundența izvoarelor. Se constituie triada putere de stat - teritoriu statal - limbă națională. Coeziunea limbilor standard crește (chiar dacă e vorba de standardizări pluricentrice, confruntate cu numeroase tendințe centrifuge - 
p. 529), dispar varietățile regionale și limbile aloglote și iau avînt 'lingvistica profanilor' și unele varietăţi populare, de tipul limbajului tinerilor și al periferiilor. Într-un ultim capitol sînt analizate contribuțiile istoriei externe, de fapt sînt rezumate concluziile părții a treia.

Partea a patra, intitulată Elemente de metodologie și de practică a cercetării (p. 539-623), se deschide cu o trecere în revistă a domeniilor metodologice, pentru cei ce doresc să se angreneze în cercetarea lingvistică, și se axează, apoi, pe două mari teme: filologia ca ramură lingvistică esențială pentru istoria idiomurilor romanice și elemente de istorie a disciplinei. Într-un preambul, autorul își exprimă regretul că, din cauza spaţiului și a complexității fenomenelor, nu a putut să trateze, aşa cum și-a propus după prima ediție a manualului, problematica izvoarelor orale din Romania.

Filologia se bucură de o abordare complexă. Se face o clasificare a genurilor textuale după mari lucrări de sinteză, sînt organizate sursele scrise, cuprinse în mari corpusuri de texte, puse în valoare de către autor, se prezintă modalităţile de codare materială şi transmitere a textelor vechi (suporturi, tipuri de scriere, tipărituri), este descrisă teoria şi practica editării de texte, mai cu seamă a celor vechi, precum și legătura dintre editare și studiu lingvistic. Pentru cei care au competențe informatice deosebite, se urmăresc diferitele elemente ale lingvisticii corpusului, de la definirea acesteia și codarea datelor textuale pînă la instrumentele de programare și analiză lingvistică și la bazele de date de referință.

Istoria disciplinei se deschide, de fapt, cu o istorie a lingvisticii și a calității de 'lingvist'. Se continuă cu paradigma istorico-comparativă în care s-au înscris vreme de mai bine de un secol științele limbii și se încheie cu paradigma modernă, valabilă mai ales de la jumătatea secolului al XX-lea. Este o adevă- rată panoramă a diferitelor discipline lingvistice, cu operele și personalitățile fondatoare sau cu un rol esenţial. Ca și în lucrarea lui I. Iordan, Lingvistica romanică. Evoluție, curente, metode, se observă foarte clar cum romanistica a jucat un rol major în apariția şi dezvoltarea altor discipline lingvistice. Perspectiva didactică asupra disciplinei nu putea lipsi dintr-o lucrare atît de cuprinzătoare (v. subcap. 4.2.4. Teorie, practică și învățămîntul romanisticii, care vădește preocuparea autorului pentru constituirea unui domeniu epistemologic coerent), cum nu putea lipsi referirea la relația dintre lingvistică și politică. Lucrarea se încheie cu un subcapitol-epilog, care se constituie într-o călduroasă pledoarie în favoarea lingvisticii.

Cartea lui M.-D. Glessgen nu este numai un manual, este mult mai mult decît atît, este un manual al manualelor, demn de luat în seamă nu numai de către studenții filologi și de către romaniști, ci de oricine se ocupă sau se apleacă asupra unui domeniu lingvistic oarecare. Ca un jucător de șah, autorul construiește cu migală, permanent, eșafodajul viitoarelor mișcări cu impact didactic. Chiar dacă, din lipsă de spațiu, anumite aspecte nu sînt tratate sau sint atinse doar, cele asemănătoare au un pronunțat caracter exemplificator și generalizator. Autorul ne poartă, ca un cicerone avizat, nu numai prin toate compartimentele limbii și ale științelor limbii, ci și prin toate epocile și spațiile care privesc Romania, combinînd permanent dimensiunea informativă cu cea formativă. Se dovedește, astfel, adevărul celor afirmate de către profesorul Alexandru Gafton în Cuvint înainte (p. 14): ,...romanistica nu este doar o știință (avînd un obiect de studiu, un instrumentar şi metode de cercetare, obiective etc.), ci și o cale de edificare a finței umane, de integrare a acesteia într-o realitate vie, dotată cu dinamism evolutiv". 